\title{
ThE THEORETICAL LINK BETWEEN TRADE AND Productivity
}

\author{
BURINSKIENE, A.
}

Abstract: This chapter presents the analysis of theoretical link between trade and productivity. Old and new trade theories, the theory of economic growth are main theories used for the analysis of trade-productivity link in the paper. In the paper trade-productivity link is analysed on different levels. On macroeconomic level the role of international trade to productivity is emphasized via import and export. Productivity change which may lead to expand countries exports and channels, through which productivity levels are interrelated, are shortly overviewed. On microeconomic level the link between trade and firm's productivity is introduced. Thinking about exporters, which need to have higher productivity level, exportproductivity premia is examined. Two most important events are recorded in history. There is the first view that the world trade was fragmented and completely nonglobalized before the 19th century, and second contrasting view about trade is globalisation and liberalisation after late 19th century. So, the effects that are delivered before and after trade liberalisation are shortly discussed in the paper as well.

Key words: productivity, trade, growth, history
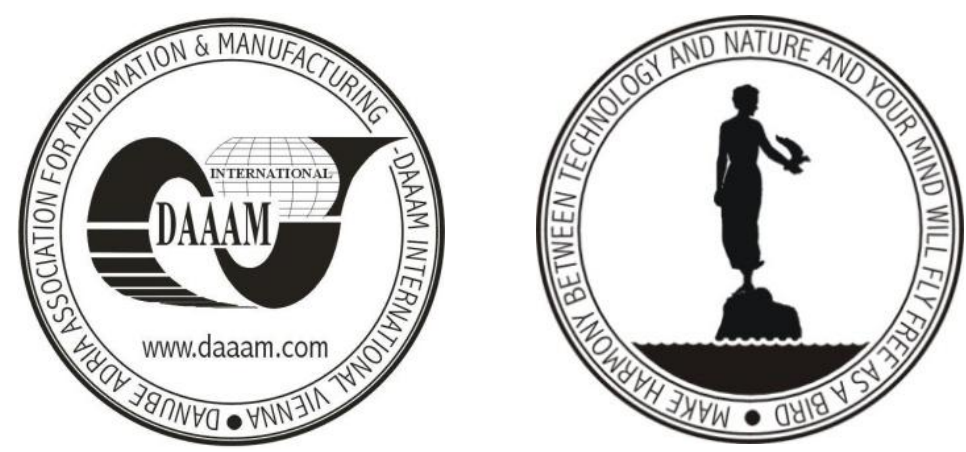

Authors' data: Dr.soc.sc. Burinskiene, A[urelija]; Vilnius Gediminas technical university, Faculty of Business Management, Sauletekio ave 11, LT - 10223, Vilnius, Lithuania, EU, aurelija.burinskiene@ vgtu.lt

This Publication has to be referred as: Burinskiene, A[urelija] (2012). The Theoretical Link Between Trade and Productivity, Chapter 25 in DAAAM International Scientific Book 2012, pp. 287-304, B. Katalinic (Ed.), Published by DAAAM International, ISBN 978-3-901509-86-5, ISSN 1726-9687, Vienna, Austria DOI: $10.2507 /$ daaam.scibook.2012.25 


\section{Introduction}

International trade became increasingly important for studies in the post-war period. The variety of trends has been noticed, such as decreases of transportation and communications costs, the developments in computer technology which are used to minimise costs of production also the share of trade in GDP has increased in all countries, and the growth rate of international trade (the sum of both exports and imports) has grown much faster than growth rate of world GDP (the sum of GDPs in all countries) in general. In addition, trade volumes increased also due to new products that were not traded before or not existed.

Due to this, there is the growing number of empiric researches where authors seek to analyse and measure links between trade volumes and productivity.

The study is organised as follows: in first part of the study theoretical link mentioned in different theories is analysed, later on the productivity measures are overviewed in the paper, and finally the effects of trade liberalisation are shortly presented. In first part, old and new trade theories, and the theory of economic growth are used for trade-productivity link analysis. There are also causal chains to analyse tradeproductivity macro and micro linkages. Some of them are overviewed in the paper.

In the second part, deeper understanding of productivity and its measurement is provided: productivity definition, different approaches to productivity measurement are presented. In the third part, the effects that are delivered before and after trade liberalisation are shortly discussed. Also the microeconomic link between trade liberalisation and firm's productivity and short-run relative advantages, brought by trade liberalisation to multinational enterprises (rather than to domestic enterprises) are introduced. The study is based on historical method and comparative analysis.

\section{The theoretical link between trade and productivity}

The idea that trade stimulates growth is known for a long time. The Ricardian model of international trade is useful tool only for thinking about the effect of international trade to national welfare. In Ricardian model labour is treated as the single factor of production and the only difference is labour productivity, which varies between industries and countries. The simple model eliminates the role of economies of scale, the difference concerning resources, takes into account an extreme degree of specialisation and permanent gains from trade for a country as a whole. Some of these predictions are even unrealistic, the number of authors have proved the basic prediction saying that countries seek to export products, for which relatively high productivity is reached (Krugman \& Obstfeld, 2003).

In the real world, comparative advantage can be reached due to differences in countries' resources. For example, Canada exports forest products to USA not because relatively higher productivity, but because of higher rate of forested land per capita in Canada than in USA. This means that talking about international trade also other factors of production such as land, capital, and mineral resources have to be taken into account. Actually Heckscher-Ohlin (HO) model explains the role of differences of resource in trade. This model shows that countries are willing to export 
products, which are intensive in factors that have a large supply relative to other resources. The open economy $\mathrm{HO}$ model assumes that multiple factors can easily move between sectors, also it predicts that, under certain conditions, the prices of factors become equal across countries with different aggregate labour productivity (Dollar \& Wolff, 1988). So, this means that HO model can help to understand only some trends in world trade history (not all of them). Thinking about trade, which influence factor prices, such ideas have to be true. The forces created by trade have to change the prices of domestic commodity, induce the movement of resources between sectors (O'Rourke \& Williamson, 1999).

Different theories of economic growth have been presented by various theorists. In these studies the diversity in growth rates between countries have been found as cause to different rates of increase in productivity per unit of factor input. By using Nishimizu and Robinson model, some authors explained, that growth rates associated with demand side, due to such changes: the growth of domestic market growth, import substitution, and export expansion (Tybout, 1991).

Two models have been suggested by economists. Import-substitution model, which required government provided tariff and quota protections, due to economic troubles in 1970s it were replaced by export-led growth model. The last model became more popular model, that International Monetary Fund recommends it to member countries. Export may in fact exert dual influence on the level of output (due to source of demand) and create room for higher import volumes. Following Kaldor (1966) definition, the long period level of output as one and the same thing with the level of output (production) ensuring equality between import and export volumes. The observed studies dedicated to productivity and export growth suggest a direct link between these just mentioned variables. The export-led growth model, presented in the literature of applied growth theory, justifies the hypothesis that export causes the productivity growth. Some explanations about this causal link are given. First, export is seen as the concentration of investments into the most efficient sectors of economy, mainly, those which have comparative advantage. Strong specialisation in such sectors cause the increase of productivity and product qualities. The next explanation is dedicated to economies of scale. The growth in export allows entities to gain from economies of scale due to size of foreign market, which is much bigger than domestic market alone. In general, this happens due to large scale of operations comparing with previous ones. The third explanation is directed to technological change. An extra competition on export sectors increase the need to keep costs low and to introduce technological change, which improves productivity. Differences in technological levels are important explaining differences in productivity. In general, technological differences mean the performance differences for exporting sectors. The last explanation is dedicated to the effect of export on other sectors. The growth of export stimulates economy as the whole via externalities of exports to other domestic sectors. So, this suggests export promoting policy (Kunst \& Marin, 1989).

The positive link between export growth and productivity growth suggest two causal hypotheses. The first one rely on idea that productivity is mainly induced by demand perspectives associated with export growth. The studies show the rapid growth of productivity growth in countries where labour productivity was initially 
low. The study of Dollar and Wolff (1988) proves this. And the second one considers that productivity as element is used to determine the rate of export growth.

The positive relation between the growth of output and productivity from time to time is used to analyse rapid investments and the scale of economies. According to Verdoorn's Law, the faster growth of output increases productivity via increasing returns. Verdoorn (1993) argues that "in the long run a change in the volume of production, say about 10 per cent, tends to be associated with an average increase in labour productivity of 4.5 per cent." Verdoorn's ideas differs from typical ones, which are met between the neoclassical models of growth. The main hypothesis "that the growth of productivity is mainly to be explained by the progress of knowledge in science and technology" (Kaldor, 1966) is used in neoclassical models of growth (for example, in Solow model). Verdoorn's law is usually associated with the cumulative causation models of growth, in which demand is used as an element more often. Kaldor (1966) and Thirlwall (1979) developed models based on Verdoorn's ideas. For a given country an expansion of the export sector may cause specialisation in the production of export products, which increases the levels of productivity and skills in the export sector. This may then lead to the reallocation of resources from the less efficient non-trade sector to the more productive export sector, bring lower prices for traded goods and higher competitiveness. This change of productivity may then lead to the expansion of exports and the growth of output.

Formal models that relate trade with technological change are presented by authors. For example, authors present framework, in which entities are catching-up international productivity levels. Rodrik (1988) presented model where positive relation between the rate of catch-up and entity's market share is found-out. Findlay (1978) developed model, which includes technology transfer between advanced country and low-technology country. The model is based on single idea - that new technologies are diffusing, because old machines are anyway depreciating. Authors mention that technology and trade are interlinked. Feenstra (1998) and Jones (2000) developed a theory which has a strong relation with Stolper-Samuelson ideas. Large entities are able to fragment their operations by improving communication. This helps them to transfer unskilled-labour-intensive operations to another countries, in which wages for unskilled labour are low.

Emphasizing the role of international trade, some recent studies, have analysed channels through which productivity levels of different countries are interrelated (Coe et al., 1997; Coe \& Helpman, 1995; Keller, 1998). It is stated in theory that there are various channels, by which technology can be transmitted across countries. One channel is related with the diffusion of technology. Technology is embodied in capital and intermediate goods so the direct import of these goods is one channel of transmission. This channel effects long-run TFP (total factor productivity) growth. These countries, which have faster growth in TFP, import more from the world's technology leaders. One note about EU new states members to be added. The new members are very different from the old ones. The new member regions are catching up technology standards of western Europe, they are dynamic with fast rising incomes, employment and changes in productivity (Baldwin \& Wyplosz, 2009). The macroeconomic link can be established between newly transferred technologies on 
output (and productivity) through imports of machinery or equipment (Teixeira \& Fortuna, 2006).

Until the 1980 old trade theory adopted different modelling approaches related to comparative advantage. In new trade models that are developed for perfect competition environment, the allocation of factors across sectors is proved. In new trade theory the impact from re-allocating resources according to comparative advantage is also taken into account.

Later on new trade theory incorporated imperfect competition and increasing returns (Baldwin, 2005). Imperfect competition is always given. As entities are facing with competitors, located in different markets. Seeking to avoid local competitors, company establishes branches across geographic markets.

The new trade theory and literature about geography and trade deepened the understanding of trade. In this theory is evident that trade and gains from it can arise due to any pattern of comparative advantage: as entities gain from economies of scale and apply the strategies of product differentiation in an imperfect competition environment. In the models, the entity is independent plan that produces one product in single location. Multi-product and multi-branch production is not included in analysis (Markusen, 1995). Taking into account John Nash's idea is that it is difficult to predict the result of the choices of multiple decision makers if their decisions are analysed in isolation. Each entity chooses a quantity to produce without knowing what quantity competitors will produce. Instead of thinking in isolation, for each player it is suggested take into account the reaction of others.

Alcala and Ciccone (2004) find-out that international trade has positive effect on productivity. The effect found is statistically robust and economically significant (Alcala and Ciccone, 2004). Other authors in their studies examined the role of institutions and geography, which is important for estimating productivity gains. From the point of view of economic geography, this presents the increase of national specialisation.

At the micro level, there can be three possible linkages between trade and productivity. First linkage between firms is vertical - the access to foreign intermediates can raise productivity because they have better quality products. Second, there are two horizontal linkage between firms. Both comes due to competition in final-goods market. First-one means that foreign competition can raise the productivity of domestic producers. Second-one - that foreign competition can force to exit the least productive domestic entities from the market (Augier et al., 2009). Authors Kox and Rojas-Romagosa (2010) analysed only those companies that started export during the years 1999-2005 and compared their productivity indicators with similar companies, which are not exporting. These export starters were not between exporting firms two years before they started export. The authors examined the changes in their each year labour productivity after they started export. No empirical support was found for this hypothesis in three years period. The authors found significant and positive learning effect on labour productivity after three years from export start in both types of companies, specialising in manufacturing and services. It is possible that companies in first three years are absorbing the extra export trade costs and "learning-by-exporting" effect is realized later on. The authors 
also found interesting insight that "learning-by-exporting" is linked with distance to technological frontier.

The comparison of productivity indicates that multinational enterprises (MNEs) are more productive than companies that are created only for export. Statistics shows that about two-third of MNEs are active in exports. Also that exporting companies are more productive than non exporting firms. In manufacturing labour productivity correlates with profitability and is higher than in companies providing services.

Authors Kox and Rojas-Romagosa (2010) analysed such groups of companies: (1) local companies with only domestic sales, (2) export companies without multinational affiliation, (3) affiliates of foreign MNEs but without exports, and (4) exporting companies with foreign multinational affiliation.

The first comparison of sole labour productivity indicates that MNEs are more productive than other exporting companies, in both sectors (manufacturing and services). In addition, labour productivity (value-added per worker) of manufacturing exporters raises with internationalisation increase. The productivity of services exporters is also become higher, but less than for producing enterprises. Sales per worker as the labour productivity indicator is relevant only for manufacturing enterprises, but not for companies in services (where domestic companies are more productive). The authors found that exporting companies (affiliate of multinational enterprise (MNE) or not) are more productive than non exporting ones. Only differences in average wages and gross profits per worker exists. MNEs tend to pay bigger wages and have higher profits than non multinational ones. Independently company belongs to MNE or not, exporters give bigger wages and earn higher profits. This means that being a part of MNE is a good factor that helps to predict orientation to export.

Exporters used to have higher productivity (than non exporting companies) allowing them to cover entry into foreign market costs. The size of company is also good indicator for starting exporter, which indicates that economies of scale are important. Authors Kox and Rojas-Romagosa (2010) thought that exporter premia is more important for small companies than for large ones, because entry to foreign market costs are relatively higher for smaller enterprises. But exporter productivity premia is found only for companies where number of employees is higher than 250 . This means that exporter productivity premia is related to economies of scale, which required seeking to cover entry into foreign markets costs. Exporting companies have also statistical and positive performance premia, which is delivered with labour productivity. For MNEs, specialising in production, premium is discovered mainly in mother companies and is less well captured in their affiliates. Statistics also show that nine out of ten exporting companies have multinational affiliation, which is common between manufacturing enterprises than enterprises specialising in services (Kox \& Rojas-Romagosa, 2010).

Concerning market structure, interesting results are reached by authors Kox and Rojas-Romagosa (2010). They discovered that exporter productivity premia is lower for companies with higher product differentiation. Authors tested export-productivity link analysing the number of product markets. They researched the services sectors and found that sectors, which are working in high competition environment, and have 
lower product differentiation, have higher export productivity premia than sectors, which are working in less competition environment. Such differences are not discovered in manufacturing sectors only.

The analysis of different theories shows that there are many potential links between trade and productivity.

\section{Productivity concept and measures}

Productivity has become a word that everyone uses it, but for different purposes. The meaning ranges from efficiency to effectiveness, to rates of turnover, to measure of customer satisfaction, changes in workflow (Oyeranti, 2000).

Several definitions of productivity may be useful here. In general, productivity - the term that refers to output per unit of input. In the context it may mean partial productivity (labour productivity, capital productivity or energy productivity, which is output per labour-hour, capital-hour or energy-hour respectively), also to multifactor productivity or total factor productivity (TFP), which adjusts labour productivity due to differences in capital and other inputs (such as energy, raw materials, etc.). Depends on the situation, which term is used. For example, OECD more often use multi-factor productivity than TFP seeking to mention that not all inputs are included in term "multi-factor productivity". Actually because of the different goals of different institutions and organisations different definitions of productivity are used (Oyeranti, 2000). In business, the change in productivity may lead to greater customers' satisfaction, improved cash flows, return on assets (ROA) and higher profit. As mentioned in economic theory, increased profits will be translated to capacity extension and creation of new job places (the reduction of unemployment). Enhanced productivity correlates with competitiveness of business and country in both domestic and foreign markets. If the higher costs of production are passed on, in order not to lose sales, the economy's industries will be oriented to the lower cost suppliers. Alternatively, if the higher costs of production are reached in internationalized industries, their profit will decrease (Oyeranti, 2000).

At national level labour productivity is translated to human productivity. The labour productivity is the measure of end result of complex process involving research and development, training, technology, other related factors (Oyeranti, 2000). And the human productivity is the measure that represents the working population and affects the purchasing power of population. As Krugman (1990) mentioned "productivity isn't everything, but in the long run it is almost everything". But still some misunderstandings exist talking about productivity. Usage of labour productivity by statistics is essential, as labour productivity usually defined as value added per full-time worker. Productivity is not just the measure, it needs to take into account other inputs used in production process. Increase in output doesn't always mean changes in productivity, as it has to be analysed together with trend of input costs. If input costs are constant than growth in productivity exists. There are three reasons why labour input is usually used for measuring partial productivity. Such as:

- labour is the most important factor of production;

- labour is the most easily quantified factor; 
- the contribution of labour to output is constantly controlled (Oyeranti, 2000).

The next confusion exists between productivity and profitability, as it is defined as gross value added minus wages and minus depreciation. Increase in productivity doesn't mean improvement in profit. Profitability increases with price changes, even when the same time productivity decreases. The last confusion exists believing that costs cutting improves productivity. Usually in long run productivity declines.

Both productivity and economic growth are important for economic progress, as it requires development in early stages and later stages, when production apparatus of domestic market is equipped. At national level, constant growth in productivity guarantees non-inflationary processes: increase in wages, solving the problems of unemployment, trade deficit and currency exchange rate (Oyeranti, 2000).

What means productivity is easy to understand, but a quantitative relationship between output and input is difficult to measure (Hall, 2011). The goal of productivity measurement is productivity improvement. In general, productivity can be measured in the context of single enterprise, industry or economy as whole. Concerning production, economic or political system, the relationship between the quantity of goods or services produced, changes in their quality and the quantity of resources used to produce them is measured (Prokopenko, 1987). So, this suggest to measure the ratio of the quantity and quality of products and resources engaged (Oyeranti, 2000). One of such measures are indexes estimated at three important levels. These are static, dynamic and surrogate levels. Static productivity ratios are linked to what occurred in a period. Dynamic productivity ratio is used to monitor changes in productivity. Two static ratios are compared for the index: the ratio of current period is compared with ratio of base period. Surrogate index is used to measure output that is difficult to measure or to collect data such as customer satisfaction, effectiveness, quality, etc. Aggarwal (1981) delivered the idea that satisfaction of employees, customers and suppliers can be measured through surrogate measures. For example, customer satisfaction can be measured by dividing total sales revenue with total number of customers. In addition, for estimating productivity change distance function can be used. Caves, Christensen, and Diewert (1982) developed Malmquist output and input indices. The output (or input) oriented index is based on an output or input distance function accordingly and reflects the changes in maximum output (or minimum input requirements) for given inputs (outputs). The geometric mean of two Malmquist output (input) indices can be used for the construction of Tornqvist output (input) index (Atkinson et al., 2003).

The approach to productivity begins from neoclassical production function. Where output is a function of inputs and time. The two most important measures of production are labour and capital. Capital is invested into the set of tool used by workers. Labour is measured $\mathrm{b}$ time spent by persons at work. Production function is used to measure maximum output possible from specified inputs. If any company invents better way to produce products (goods and services), the output will be higher from the same amount of inputs. More complicated measure can be used for technological change. In more involved applications labour, capital, and intermediates and their changes in quality are analysed. For example, Tornqvist index can be used for such analysis. A Tornqvist index summarizes labour input connected 
to the growth rate of the hours of each group of workers by the share of labour compensation they receive due to change.

Total factor productivity (TFP) has a critical role on economic growth, economic fluctuations, and income per capita differences. Solow (1956) demonstrated that cross-country differences in technology may generate crosscountry differences in income per capita. Understanding the determinants for the adoption of technology is important explaining differences in TFP. On one side, these differences in TFP may be due to different technologies used in countries or the way, in which these technologies, are used. On another side, the quantity and type of resources used in production process and their utilisation also matters. On the third side, authors are also linking the implementation of technologies with market specifics, financial conditions, the role of institutions and policies (Comin, 2006).

Antle and Capalbo (1988) identified two main approaches used for TFP measurement: index number approach, econometric approach, and traditional approach. With the marginal productivity theory, growth of output decomposes into growth of labour, capital, land, knowledge and other sources. To measure output growth the weighted sum of all inputs is used. Laspeyres indexing procedure is known as a "base-weighted" or "fixed-weighted", which imply a linear production functions, in which all inputs are perfect substitutes in production process. In addition, Cobb-Douglas function may be used to represent the relationship of output and two inputs. The only limitation of index number approach to include effects of economies of scale, technology change and inputs substitution. The econometric approach to productivity measurement is estimation of production function or dual cost or profit function seeking to establish direct linkages of productivity growth between key characteristics. Traditional approach to productivity measure is used seeking to observe the best practice output (frontier output). It uses frontier framework for that. Malmquist productivity index is good example of this last approach (Oyeranti, 2000).

Productivity as a source of growth used in analyses of growth of economy in last years. The focus is the growth of labour, capital and other resources (Ahluwalia, 1991). Two main sources, used to estimate economic growth in output, is the increase in factors of production (labour and capital devoted to production) and productivity gains that enable an economy to produce more by using the same amount of inputs (Baldwin et al., 2001). Possible linkages between productivity growth and trade regime is often analysed through TFP growth. This means that labour, capital, and materials and their changes in quality are analysed and aggregated using the measure of total factor productivity index. The only problem that in practice, both measurements of outputs and inputs involve aggregation problem. For example, the question of how to aggregate different products that don't have constant quality or characteristics. The problem remains seeking to aggregate the different types of inputs into one input measurement. That's why partial productivity measures have advantage because of their simplicity, flexibility and data availability.

Looking back to the issue of productivity growth, it has to be mentioned that TFP growth rates correlate with fluctuations in output. TFP strongly correlates with output and input when business cycle appears, because business decisions to innovate 
have significant implications for the business cycle (Comin, 2006). Some remarks are given for these studies. It is more easy to find association between rapid output and rapid export growth. Some cross-country studies also conclude positive correlation between productivity and export growth. In addition, there are single-country studies, which examine correlation between TFP growth within country and the openness of trade, and multi-country studies, which study industry level TFP indices. Many single-country and multi-country CGE (computational general equilibrium) models incorporate causal chains for analysing trade-productivity link (Robinson et al., 2006).

Some authors have analysed the effect of location on productivity, which varies among rural and urban areas. The location factor is different within industries, among industries and it changes over time, as size of distribution changes as well. Entry and exit patterns, foreign competition can affect the distribution of branches, economies of scale. These also affect industry-level productivity. Keeping these links, relation between trade regimes and the size branch distribution can be examined. Tybout (1991) mentioned that larger branches usually are exporters. Authors suggested many models of trade, which include imperfect competition and the size of branch distribution. Empirical researches show that bigger adjustments in distribution occurs due to the entries or exits of firm in market. Also results shows that open economy leads to new gains through the reaching branch-level scale economies (Tybout, 1991). Foreign competition forces branches, which are below the efficient scale, to exit; foreign competition improves the usage of new technologies (the increase of technology acceptance is seen between industries). Some studies have included also the maturity of branch for the choice of technology, but still very little has been done.

In addition, some authors, such as Irwin and Tervio (2002), Rodriguez and Rodrik (2001), Rodrik (2000) argue that trade is not the significant determinant of productivity when geography factors and the estimates of institutional quality are included in empirical analysis (Alcala \& Cissone, 2004).

Productivity has great importance in economic analysis. For example, productivity trend combined with other trends (population and output trends) is used in economic growth models to forecast changes. Usually it is used to forecast output, as well as the distribution of resources between different sectors of economy or industry. Actually, productivity is used for analyzing the relative dynamism of different economic activities. Also, the interest in productivity is related with ability to know the process of technical change. This means that economic growth, productivity, and technical change are closely related. The only obstacle to measure the growth of productivity more precisely is aggregation of production factors; scientists have been dealing with problem for more than 30 years.

\section{The effects before and after trade liberalisation}

The definition about trade liberalisation might be useful before starting analysis. Trade liberalisation - the term used to describe process when country opens its market to international trade by reducing taxes (talking about tariffs) and other limits (non tariff barriers) for incoming and outcoming products. 
Before the early 19th century, when industrial and transport revolution happened, Adam Smith raised ideas of free market economies which are more productive and beneficial to nations. Trade, in Adam Smith period, was strictly limited to what we can call non-competing goods: Europe and Asia imported products which were not found in these continents at all. Initially, only products, which had very high value, were shipped, such as silk, linens and woolens, sugar, exotic spices, silver and gold. The 19th century is the classic Heckscher-Ohlin (HO) era, when transport costs declined. Unprecedented levels of labour and capital transfers happened in late 19th century: 60 million of Europeans were moving over Atlant ocean. Moreover, the exchange of agricultural products and manufactured goods between Europe and North Atlantic improved, but land was a crucial factor for agriculture in New World not labour and capital. The trade flows between other continents improved when shipping and port technologies developed, and the number of international conflicts reduced. The range of goods traded dramatically extended over time due to changes in trade regimes.

Old trade theory, based on theoretical Heckscher-Ohlin-Samuelson and VinerMeade frameworks, provided a strong set of tools for analyzing issues arising not only from the formation of free trade agreements, but also from trade liberalization (Robinson et al., 2006). The main problem, which rises, that these models can't accommodate two-way trade. An alternative focus regarding two-way trade is taken by constructing trade-focused CGE models. In these models domestic and imported products (which belong to the same commodity classification) are treated as imperfect substitutes (in demand) and the elasticity of substitution (CES) is included and the price ratio of imported and domestically produced commodities is analysed.

The standard trade-focused CGE (computable general equilibrium) model was developed in the late 1970 and had some limitations in capturing historical trends and important effects that are recognized as empirically important. The main effect of liberalisation is the effect the volume of inputs needed to produce the given volume of outputs (Tybout, 1991). World trade organisation (WTO) studied situation before and after trade liberalisation and figured out that exports (especially manufacturing export volumes), investments are growing up after trade liberalisation (Salinas \& Aksay, 2006). The opening of domestic market to external markets ensures the better allocation of resources and promotes the orientation of investments to potential exporting sectors, which previously traded in domestic markets mainly.

In the early papers of Bernard, Eaton, Jensen and Kortum (2003) and Melitz (2003) authors focus on productivity effects of trade liberalisation. Before discussing these results, small study on questions that arise with trade liberalisation is provided below.

The author studies small-versus-big firm arrangements. To keep presentation simple the author assumes that there are two firms (entities) - one large, one small in EU. The supply curve of large entity is reflecting the larger company's greater efficiency. As supply curve shows marginal costs, the smaller supply curve means that the larger entity has smaller marginal costs for different output level. In case of smaller entity supply curve will be higher, so a given world price will enable to operate for large entity only. Small entity will have to finish production since the 
world price will be lower its marginal costs even in case, when small quantity is produced by entity. If the price floor is added then both entities produce output. The total output will be the sum of two outputs: small and big outputs, where small output is delivered by small entity and big one - by the large entity.

On the other hand, the surplus generated by producers is distributed accordingly: small surplus is earned by small (high cost and low technology) entity and the large one - by large (low cost and modern technology) entity. Due to this, large entity tends to be richer and supports trade liberalisation, while small entity doesn't support it. In such case, the introduction of policy for small entities is suggested.

The microeconomic link between trade liberalisation and firm's productivity are modelled by Bernard, Eaton, Jensen and Kortum (2003), Eaton and Kortum (2002). Rodrik (1988) suggested the framework, in which entities are catching up international productivity levels based on their market share. The positive relation between these two variables is find-out by the author (Rodrik, 1988). For some of such studies Herfindahl index (concentration ratio) to measure market share of large entities is used. In addition, talking about international productivity levels, Rodrik (1988) argues that domestic producers choose the way to compete with new competitors via the choice of technique. They are protecting foreign competition by failing to modernize old branches. And this helps them to have lower output prices.

Bernard, Redding and Schott (2006) analyse multi-product firms and analyzes their behavior during trade liberalization. He mentioned that higher firm-level ability raises entity's productivity across all products. After trade liberalisation, exporters, which produced the smaller range of products before it, increase the range of products sold abroad and export volumes for each product.

Trade liberalisation also change allocation of production branches. MNEs will increase the scale of production for each product. In order not to duplicate fixed costs, these entities will not produce the same product in several countries after the economies of these countries become integrated. MNEs will specialize the production in each branch. With new economic opportunity that is delivered after trade is liberalized - export to foreign country become possible. Two basic effects are seen. Once, the trade is liberalized, MNEs find the capacity bigger than domestic enterprises. Second, MNE face smaller entry costs into foreign market - smaller information costs and costs for establishing distribution and service network, introducing brand name and confirming the products with foreign market regulations. On the other hand, the fixed costs for entering into foreign market may prevent domestic entities to enter it. So, MNE has relative advantage in short-term. In longterm new entities could enter both markets, where affiliates of MNE are present. Also MNE can easily buy foreign counterpart and distribute technology faster than domestic enterprises may do (Hallak, 2000).

As it is worth to have competitive advantage for each nation, each of them will have some products that are relatively expensive and some products that are relatively cheap. This effect of comparative advantage is known as Heckscher-Ohlin (HO) comparative advantages' effect (Baldwin \& Wyplosz, 2009). Of course, trade liberalisation in Europe allowing for many nations (not only for two ones) to specialize in producing goods that are relatively cheap and importing goods that are 
relatively expensive. So, this means that the liberalisation of trade brings welfare only if entities in the country are well prepared to face foreign competition, because extra competition can force entities to expand or exit. Instead the loss of productivity, the country gains from trade (Helpman \& Krugman, 1987). One reason for that is enlarged country's consumption possibilities opening also new chance for productivity increase. But none of delivered frameworks, presented by Baldwin (1989), Dixit (1989), describes why trade regime affects long run growth in productivity. Trade regime affects the rate of productivity growth due to these reasons. First, thinking about new products, the variety of available substitutes is considered. Second, there is demand, which is higher in larger markets for any variety of products. These effects are contrasting ones. In addition, the development and production of new products, requires new inputs of capital and labour. This means that imported capital equipment may need implementation of advanced technologies at which one enterprises are better than other ones (Augier et al., 2009).

If both entities (home and foreign) have the same marginal cost, no one would export, because there will not be possible for exporter to earn some profit. So, this means that all identical entities will lose and will be against trade liberalisation.

The classic implementation on liberalisation starts from lowering marginal trade costs, but leaving many of other trade barriers, which are subject to regulation and standards, which makes difficulties to introduce into market products, which are produced in foreign country. These are called technical barriers to trade (TBTs). Some of them are remaining among Japan, Canada, US and EU. In Western Europe classic trade barriers are eliminated in 1975, TBTs during the last decades. TBTs are liberalised in such main ways. The first way, when two or more nations adopt common standards. For example, EU and US set standards and other nations follow them. The second way, the nations recognise the standards of each other and sign mutual recognition agreement (MRA). For example, in $1998 \mathrm{EU}$ and US have signed MRA to certify the compliance of products (Baldwin \& Forslid, 2004).

Productivity is the crucial performance variable in the heterogeneous-companies trade models (Melitz, 2003; Baldwin, 2005). Exporters need to have higher productivity (than non exporting companies) seeking to absorb the fixed costs or sunk entry costs (one-time entry costs that can't be returned back) met in the foreign market. Helpman, Melitz and Yeaple (2004) in their study indicate that sunk entry costs are stronger for companies in services than for production companies.

Authors Kox and Rojas-Romagosa (2010) analysed productivity premia and they predicted that productivity premia exists for exporting and MNEs. And if they exist, whether such effects can possibly be explained assuming various companyspecific, industry-specific and market-specific factors.

Both effects: reallocation effect of output at different branches and productivity growth effect at individual branches are the main sources of productivity growth at industry level. These effects can be explained only together. Authors Navas-Ruiz and Sala (2007) added into their model the possibility for companies to adopt more costly productive technologies and showed that production branch productivity increases in response to lower trade costs. Following trade liberalization, the selection of export increases the market share only for some exporting companies. Therefore, the greater scale of operations increases exporters return from costly productivity related investments, since trade liberalization entails a larger access to product markets and a 
higher demand for company's product increases production capacity of domestic exporters, also returns from technology adoption. In addition this leads exporters to implement more innovative technologies (Navas-Ruiz \& Sala, 2007).

Four effects which imply the gains from trade liberalization. Two effects tend to lower welfare while the others tend to raise it. The first effect is Melitz anti-variety effect (the number of varieties consumed drops), the second - the Melitz productivity effect, the third - MacDonalisation effect, and the fourth one is share-shifting effect (Baldwin \& Forslid, 2004). First, Melitz variety effect is contrasting with Krugman variety effect, as in Krugman model the freer trade double increase the number of varieties, which become available to consumers. Second, Melitz (2003) showed that liberalisation affect strongly the average productivity. He presented the strong impact of trade liberalisation on average productivity of industry (Baldwin \& Forslid, 2004). Third, freer trade increase share of imported varieties in consumer baskets, because imported varieties will be cheaper and this improves the choice of individuals. Fourth, share-shift analysis is applied for international trade. Share-shift is used for the analysis of the growth of exports by splitting it into four separate components. The first one is global component, which indicate changes due to overall growth of world trade; the second one - geographical component, which indicates changes in the distribution of country's trading partners; the third one - product composition component, which indicates the growth due to the mix of products exported, and the last one - performance indicator, which indicates changes in competitiveness. The first three components are used to predict expected proportional changes in trade and the fourth one - to eastimate shifts between expected proportional changes (PiezasJerbi \& Nee, 2009).

Melitz (2003) shows impact of liberalisation on average productivity of industry via:

selection effect and production reallocation (from the least to the most efficient firms) effect. It seems that exporters need to have higher productivity than non exporting companies as they have to cover entry costs into foreign market seeking to become exporters. Static productivity premia is analysed by using the data, which covers long-time exporters, new exporters and non exporting companies. The authors Kox \& Rojas-Romagosa (2010) did some tests with new exporters (export starters) and non exporting companies. Authors were searching for positive productivity premia before start of export on the basis of their performance in domestic markets. They discovered that labour productivity and profitability for production company in year i-3 is a good indicator to start export in year i. A marginal increase in labour productivity before 3 years stimulates the positive export decision and later on the export is started. The indicators are strongest in production companies, for companies in services indicators indicate export start 2 years before the start. The small number of export starters have significant and positive productivity results in year i-2 (2 years before) before actual start (Kox \& Rojas-Romagosa, 2010).

Exporting companies are more productive and theoretically are bigger (talking about sales, number of employees, generated value-added, capital), and paying higher wages than non exporting firms. Two hypotheses have been formulated to research export productivity premia. This hypothesis can be named "learning-by-exporting" hypothesis, which tells that companies become more productive after they begin to export. The second hypothesis tells that the most productive companies, which can 
overcome trade costs (entry costs into foreign market) and become exporters (Kox \& Rojas-Romagosa, 2010). Exporting (high-productivity) companies expand and non exporting (low-productivity) companies exit the market. The first tests authors Kox and Rojas-Romagosa (2010) did seeking to find productivity premia for exporting companies. Authors found fairly significant performance differences between purely domestic companies, exporting firms and the affiliates of MNEs.

So, the change in trade regime affects the output prices, returns from the development of new products (via Stolper-Samuelson linkages), and influences the rate of productivity growth.

\section{Conclusion}

Productivity has great importance in economic analysis. Combined productivity trend with other trends (population and output trends) is used in economic growth models, usually to forecast output, as well as the distribution of resources between different sectors of economy or industry. The analysis of different theories (old and new trade and economic growth theories) shows that there are many potential links between trade and productivity.

These links are also found on macroeconomic and microeconomic levels. At macroeconomic level constant growth in productivity guarantees non-inflationary processes in country: increase in wages, solving the problems of unemployment, trade deficit, and currency exchange rate. On microeconomic level higher productivity is found among exporting, especially among multinational enterprises. Research proved that the labour productivity of export firms raises with the increase in internationalisation.

The implementation of trade liberalisation means the lower marginal trade costs and the removal of other trade barriers, which are related to regulation and standard. Also country opens its market to international trade by reducing all barriers (including technical barriers to trade as well) for incoming and outcoming products. But the old trade theory, based on theoretical Heckscher-Ohlin-Samuelson and VinerMeade frameworks, can't accommodate two-way trade. This alternative focus regarding two-way trade is taken by constructing trade-focused CGE models. Possible macroeconomic linkages between productivity growth and trade regime is often analysed through total factor productivity growth. There are two reasons when countries, instead of losing productivity, have gains from trade liberalisation. The first reason for that is demand, which is higher in larger markets for any variety of products. The second reason for that is enlarged country's consumption possibilities opening also new chance for productivity increase.

The microeconomic link between trade liberalisation and firm's productivity shows that entities are catching up international productivity levels based on their market share. In addition, trade liberalisation brings relative advantage to multinational enterprises in short-run. Also changes the allocation of production branches and raises entity's productivity across all products. But in general, liberalisation brings welfare only if entities in specific country are well prepared to face foreign competition.

The main effect from liberalisation comes when the opening of domestic market to external markets ensures the higher export, better allocation of resources and 
promotes the orientation of investments to potential exporting sectors, which previously traded in domestic markets mainly. The change in trade regime also affects the output prices, returns from the development of new products (via StolperSamuelson linkages), and influences the rate of productivity growth.

The research is limited and not covers the situation of small countries. Small and open economies are more susceptible to large external shocks, such as changes the terms of trade, regional contagion effects and other ones. Many of them have diversified trade structures (small countries are dependent on Europe, US, Japan, and intra-Asian trade). So, this is the objective of further research.

\section{References}

Ahluwalia I. J. (1991). Productivity and Growth in Indian Manufacturing, Oxford University Press, ISBN 10: 0195627636, Delhi

Alcala, F. \& Ciccone, A. (2004). Trade and productivity. The Quarterly Journal of Economics, May 2004, 353-402, ISSN 1531-4650

Atkinson, S. E.; Cornwell, C. \& Honerkamp, O. (2003). Measuring and decomposing productivity change: stochastic distance function estimation versus data envelopment analysis. Journal of Business \& Economic Statistics, Vol. 21, No. 2, 284-294, ISSN 1537-2707

Augier, P.; Cadot, O. \& Dovis, M. (2009). Imports and TFP at the firm level: the role of absorptive capacity, Available from: http://www.cepremap.ens.fr/depot/docweb/docweb0903.pdf Accessed: 2012$07-31$

Baldwin, R. (1989). Sunk-cost hysteresis, Available from: www.nber.org/papers/w2911 Accessed: 2012-08-02

Baldwin, J. R.; Harchauoui, T. M.; Hosein, J. \& Maynard, J. P. (2001). Productivity: Concepts and Trends, In: Productivity Growth in Canada, Baldwin, J. R.; Beckstead, D.; Dhaliwal, N.; Durand, R.; Gaudreault, V.; Harchaoui, T. M.; Hosein, J.; Kaci, M. \& Maynard, J. P. (Ed.), 13-24, Statistics Canada, ISBN 978-1-100-20493-2, Canada

Baldwin, R. E. \& Forslid, R. (2004). Trade Liberalization with Heterogenous Firms, Available from: www.cepr.org Accessed: 2012-08-01

Baldwin, R. E. (2005). Heterogeneous firms and trade: testable and untestable properties of the Melitz model, Available from: www.nber.org Accessed: 201208-04

Baldwin, R. E. \& Wyplosz, C. (2009). The Economics of European integration. McGraw-Hill Education, ISBN-10: 1845423771, UK

Bernard, A. B.; Eaton, J.; Jensen, J. B. \& Kortum, S. (2003). Branches and Productivity in International Trade. American Economic Review, Vol. 93, No. 4, 1268-1290

Bernard, A. B.; Redding, S. J. \& Schott, P. K. (2006). Multi-product firms and trade liberalization, Available from: http://mba.tuck.dartmouth.edu Accessed: 201207-30

Caves, D. W.; Christensen, L. W. \& Diewert, W. E. (1982). The economic theory of index numbers and the measurement of input, output, and productivity. Econometrica, Vol. 1, No. 50, 1393-1414, ISSN 1468-0262 
Comin, D. (2006). Total factor productivity, Available from: www.people.hbs.edu/dcomin/def.pdf Accessed: 2012-07-28

Coe, D. T.; Helpman, E. \& Hoffmaister, A. W. (1997). North and South spillovers. Economic Journal, Vol. 1, No. 107, 134-149, ISSN 1468-0297

Coe, D. T. \& Helpman, E. (1995). International R\&D spillovers. European Economic Review, Vol. 1, No. 39, 859-887, ISSN 0014-2921

Dixit, A. (1989). Hysteresis, import penetration and exchange rate pass-through, Quarterly Journal of Economics, Vol. 104, No. 2, 207-228, ISSN 1531-4650.

Dixit, A. (1989). Entry and Exit Decisions under uncertainty. Journal of political economy, Vol. 97, No. 3, 620-638, ISSN 0022-3808

Dollar, D. \& Wolff, E. N. (1988). Convergence of industry labor productivity among advanced economies 1963-1982. The Review of Economics and Statistics, November 1988, 549-567, ISSN 0034-6535

Eaton, J. \& Kortum, S. (2002). Technology, Geography and Trade. Econometrica, Vol. 5, No. 70, 1741-1780, ISSN 1468-0262

Feenstra, R. (1998). Integration of Trade and Disintegration of Production in the Global Economy. Journal of Economic Perspectives, Vol. 4, No. 12, 31-50, ISSN 0895-3309

Findlay, R. (1978). Relative backwardness, direct foreign investment, and the transfer of technology: a simple dynamic model. The Quarterly Journal of Economics, Vol. 1, No. 92, 1-16, ISSN 1531-4650

Hall, B. H. (2011). Using productivity growth as an innovation indicator, Available from: http://ec.europa.eu/commission Accessed: 2012-07-31

Hallak, J. C. (2000). Domestic firms vs. multinationals: the effects of integration, Harvard University Press, ISBN 071463406 9, Harvard

Helpman, E. \& Krugman, P. R. (1987). The Market structure and foreign trade: increasing returns, imperfect competition, and the international economy, MIT Press, ISBN-10: 026258087X, Cambridge

Helpman, E.; Melitz, M. J. \& Yeaple, S. R. (2004). Export Versus FDI with Heterogeneous Firms. American Economic Review, Vol. 1, No. 94, 300-316, ISSN 0002-8282

Jones, R. W. (2000). Globalization and the Theory of Input Trade, MIT Press, ISBN 026210086X, Cambridge

Kaldor, N. (1966). Causes of the Slow Growth in the United Kingdom, Cambridge University Press, ISBN 88-7999-532-4, Cambridge

Keller, W. (1998). Are international R\&D spillovers trade-related? Analyzing spillovers among randomly matched trade partners. European Economic Review, Vol. 1, No. 42, 1469-1481, ISSN 0014-2921

Kox, H. L. M. \& Rojas-Romagosa, H. (2010). Exports and productivity selection effects for Dutch firms, Available from: www.gredeg.cnrs.fr Accessed: 2012$08-10$

Krugman, P. (1990). The Age of Diminished Expectations. MIT Press, ISBN-10: 0262-61092-2, Cambridge

Krugman, P. R. \& Obstfeld, M. (2003). International economics: theory and policy. Pearson Education International, ISBN 0-321-07727-x, Boston

Kunst, R. M. \& Marin, D. (1989). On exports and productivity: a causal analysis. The Review of Economics and Statistics, Vol. 71, No. 4, 699-703, ISSN 0034-6535. 
Markusen, J. R. (1995). The Boundaries of MNEs and the theory of international trade. Journal of Economic Perspectives, Vol. 9, No. 2, 169-189, ISSN 08953309

Melitz, M. J. (2003). The impact on intra-industry reallocations and aggregate industry productivity. Econometrica, Vol. 1, No. 71, 1695-1725, ISSN 14680262

O'Rourke, K. H. \& Williamson, J. G. (1999). The Heckscher-Ohlin model between 1400 and 2000: when it explained factor price convergence, when it did not, and why, Available from: www.unav.es/economia Accessed: 2012-08-14

Oyeranti, G. A. (2000). Concept and measurement of productivity, Available from:

http://www.cenbank.org/out/Publications Accessed: 2012-08-06

Piezas-Jerbi, N. \& Nee, C. (2009). Market shares in the post-Uruguay round era, World Trade Organisation, ISBN 978-92-870-3748-0, Geneva

Prokopenko, J. (1987). Productivity Management: A Practical Handbook, International Labour Organization, ISBN 9221059014, Geneva

Robinson, S.; Burfisher, M.; McDonald, S. \& Thierfelder, K. (2006). Deep Integration and Trade Productivity Links: Tentative Lessons for CGE International Trade Models, Proceedings of GTAP Annual Conference, Deardorff, A. (Ed.), pp. 1-12, ISSN 2160-2115, Ethiopia, June 2006, Center for Global Trade Analysis, USA

Rodrik, D. (1988). Imperfect competition, scale economies and trade policy in developing countries, In: Trade policy issues and empirical analysis, Baldwin, R. (Ed.), Chicago Press for NBER, ISBN 0-226-03607-3, Chicago

Rodrik, D. (2000). Estimating the Effects of Currency Unions on Trade and Output, Harvard University, ISBN 0-821-35000-5, Harvard

Rodriguez, F. \& Rodrik, D. (2001). Trade Policy and Economic Growth: A Skeptic's Guide to the Cross-National Evidence, In: NBER Macroeconomics Annual 2000, Bernanke B. S. \& Rogoff, K. (Ed.), 261-338, MIT Press, ISBN 0-26202503-5, Cambridge

Salinas, G. \& Aksay, A. (2006). Growth before and after trade liberalisation, Available from: www-wds.worldbank.org Accessed: 2012-08-08

Solow, R. (1956). A Contribution to the Theory of Economic Growth. Quarterly Journal of Economics, Vol. 70, No. 1, 65-94, ISSN 1531-4650

Teixeira, A. A. C. \& Fortuna, N. (2006). Human capital, trade and long-run productivity: testing the technological absorption hypothesis for the Portuguese economy 1960-2001, Available from: wps.fep.up.pt/wps Accessed: 2012-08-12

Thirlwall, A. P. (1979). The balance of payments constraint as an explanation of international growth rate differences. Banca Nazionale del Lavoro Quarterly Review, March 1979, 429-438, ISSN 2037-3643

Tybout, J. (1991). Researching the trade-productivity link: new directions, World Bank Publications, 1-58, Washington

Verdoorn, J. P. (1993). On the Factors Determining the Growth of Labor Productivity, In: Italian Economic Papers, Pasinetti, L. (Ed.), 49, Oxford University Press, ISBN-10: 0198287690, Oxford 